\title{
PENGEMBANGAN PENDEKATAN PEMBELAJARAN \\ BERBASIS MULTIPLE INTELLIGENCES \\ BAGI MAHASISWA S1 PGMI IAIN SNJ CIREBON
}

\author{
Atikah Syamsi \\ Dosen Prodi Pendidikan Guru Madrasah Ibtidaiyah \\ IAIN Syekh Nurjati Cirebon
}

\begin{abstract}
To support efficacy of study, basically to determine approach of study which in line with curriculum. Studying approach of study, a lot of type approach of which can applied. Among others approach of developed study from an recognized theory with theory of Multiple Intelligence. The Theory used as by approach of study, because it talk about variety which related to educative participant interest. Basically in each of curriculum is focus to attainment an certain interest to educative participant. Approach of Multiple Intelligence even also look into that human being or someone have some intellegence potency. One of the intellegence educative by participant that's which must be developed, so that in the end become an its very dominant interest.

One of the matter which need to be paid attention in Multiple Intelligence is the existence of education institutes responsibility to be succeeding to find at least one ability region matching with its intellegence potency and this matter have positive implication to make-up of its life or which is ordinary to be recognized with term of make-up of life skills. Quality of Indonesia human resource these days is reflection of education system which in this time go into effect.

This research represent Research and Development (having the character of research applied) that is research used to look for, to developing and testing an certain finding or product. This Research type is research of Experiment with approach of mixture that is qualitative and is quantitative, where this research aim to develop new approach that is intelligences multiple to student of PGMI IAIN SNJ Cirebon. This Matter because of the importance of education which peculiarly refer at student skill soft as behavioral base of academic, namely for example mirror of education base on intelligences multiple which practically can improve efficiency of someone life and it is of course also be benefit to its environment. By having efficiency of life which is good to be, expected by all college grad will be able to solve life problema faced,
\end{abstract}

Key words : Multiple intelligences, Life Skills, kecerdasan, Mahasiswa, Pendidik 


\section{Pendahuluan}

Praktik pendidikan yang banyak kita temui di sekolah-sekolah formal khususnya di Indonesia, dengan jelas menunjukkan bahwa penghargaan terhadap perbedaan antar individu peserta didik masih sangat kurang. Artinya bahwa aspek psikologis yang merupakan faktor penting yang harus diperhatikan dalam proses kegiatan belajar mengajar masih sering diabaikan. Salah satu bukti akan hal ini misalnya dapat dilihat, bahwa pendidikan yang dilaksanakan selama ini cenderung lebih mengutamakan pada terlaksananya kurikulum. Artinya, peserta didik dipaksa untuk mengikuti segala hal yang ada dalam kurikulum. Sementara pendidik berperan sebagai fasilitator yang mengusahakan bagaimana peserta didik bisa mengikuti kurikulum, seharusnya proses pendidikan harus memperhatikan peserta didik secara psikologis. Sebab, tanpa adanya perhatian dari sisi psikologis ini maka proses pendidikan yang dilaksanakan jelas akan kehilangan arah. (Subandijah,1996:36)

Secara lebih spesifik misalnya, dari aspek penilaian. Seorang peserta didik dianggap cerdas apabila memiliki IQ yang tinggi. Sementara peserta didik yang memiliki IQ rendah dianggap sebagai orang yang bodoh. Peserta didik disini maksudnya tidak terkecuali pada tingkatan pendidikan tinggi. Padahal penilaian dari IQ tersebut hanya merupakan bagian kecil dari keseluruhan kecerdasan yang sebenarnya. Penilaian terhadap mahasiswa hanya dari satu segi saja inilah salah satu sikap yang mendiskriminasikan peserta didik dalam proses kegiatan belajar mengajar.

Kullu mauluudin yuuladu 'alal fithrah. Setiap manusia dilahirkan dengan membawa potensi (fitrah) yang sama. Termasuk dalam hal ini adalah bahwa setiap manusia memiliki potensi (fitrah) kecerdasan yang sama, dalam hal ini kecerdasan didefinisikan Gardner sebagai suatu kemampuan untuk menyelesaikan masalah atau menciptakan sesuatu yang bernilai dalam suatu budaya. (Armstrong, 2002 : 19) Kecerdasan tersebut memiliki banyak jenis. Akan tetapi, diantara berbagai kecerdasan yang dimiliki manusia akan menunjukkan derajat perkembangan yang berbeda. Potensi kecerdasan yang dimiliki oleh manusia akan berkembang sesuai dengan lingkungan dimana manusia tersebut berada. Oleh 
karena itu, kecerdasan tersebut akan memiliki pola perkembangan yang berbeda antar satu individu dengan individu lainnya. Menurut Gardner, pada dasarnya sebagian dari peserta didik memiliki karakter yang menjanjikan dan sebagian lain memiliki karakter yang beresiko. (Jasmine, 2007 : 64) Proses identifikasi ini penting dilakukan oleh seorang pendidik. Peserta didik dikatakan menjanjikan apabila peserta didik memiliki kemampuan yang sangat khusus dan menonjol. Kemampuan tersebut merupakan kristalisasi dari berbagai pengalaman, respon emosi yang sangat mendalam yang memusatkan perhatian dan usaha para individu tersebut untuk menuju kearah tertentu. Sedangkan, peserta didik yang memiliki karakter beresiko maksudnya adalah bahwa seorang peserta didik dapat ditolong dengan memberikan bantuan secara intensif.

Implikasi dari pengenalan, pengakuan dan penghargaan terhadap kecerdasan yang dimiliki oleh setiap individu peserta didik harus menjadi landasan dalam menentukan setiap kebijakan dalam proses pendidikan. Implementasi kecerdasan majemuk dalam pendidikan ini salah satunya yaitu dengan adanya kurikulum yang mampu memfasilitasi pembelajaran di kelas sehingga bisa mengembangkan seluruh kecerdasan dari para peserta didik. Jadi, pada intinya adalah bahwa kurikulum harus disusun dengan memperhatikan halhal (kelebihan) yang dimiliki oleh tiap-tiap peserta didik. (Hoerr, 2007 : 14). Kurikulum harus bisa digunakan sebagai suatu sarana bagi institusi untuk mengembangkan Kecerdasan Majemuk yang dimiliki oleh masing-masing peserta didik.

Dalam buku "Gurunya Manusia" dijelaskan bahwa strategi mengajar itu mengandung unsur-unsur metode, prosedur aktivitas dari metode tersebut, yang di dalamnya ada istilah teknik dan trik, lalu terakhir adalah penilaian. (Chatib, 2011) Sebuah ilustrasi yang diceritakan penulis Buku tersebut, Ketika beliau mengajar di jenjang TK sang penulis memilih strategi SOSIO DRAMA atau roleplay, demikian juga ketika mengajar SD kelas 5 menggunakan stategi yang sama. Dan ketika beliau menggunakan strategi sosio drama itu ke jenjang SMP dan SMA, hasilnya luar biasa. Semua siswanya sangat antusias mengikuti proses belajar. Ketika mengunakan strategi sosio drama di kampus, para mahasiswa 
menyambutnya dengan dahsyat. Lalu apa yang membedakan strategi itu pada setiap jenjangnya, ternyata kesimpulannya Pastilah pada unsur prosedur aktivitas dan penilaiannya. Munif Chatib berpendapat, teman-teman guru yang mengatakan bahwa strategi multiple intelligences hanya cocok untuk jenjang TK dan SD mungkin disebabkan kurang pahamnya terhadap 'ruh' strategi mengajar itu sendiri. Banyak pendidik yang terjebak ketika mengajar pada tingkat SMP, SMA dan perguruan tinggi, hanya menggunakan strategi tunggal yaitu metode ceramah. Padahal betapa banyak siswa dan mahasiswa yang mengantuk pada saat guru dan dosennya berceramah.

Berdasar pada latar belakang masalah diatas, maka penulis mengajukan 3 rumusan masalah yang akan dikaji lebih lanjut, yaitu :

1. Bagaimana urgensi model pembelajaran berbasis multiple intelligences dikembangkan pada tingkat Perguruan Tinggi ?

2. Bagaimana Implementasi Pengembangan pembelajaran berbasis multiple intelligences bagi mahasiswa S1 PGMI IAIN SNJ Cirebon ?

3. Bagaimana implikasi pembelajaran berbasis multiple intelligences terhadap peningkatan life skill bagi mahasiswa S1 PGMI IAIN SNJ Cirebon?

\section{Tinjauan Pustaka}

Penelitian yang membahas tentang teori kecerdasan ini antara lain yaitu penelitian yang dilakukan oleh Eman Revlan dengan judul penelitian "Pendekatan Multi Kecerdasan Menurut Howard Gardner dan Implilkasinya bagi Pembelajaran Pendidikan Agama Islam". Penelitian ini membahas tentang konsep kecerdasan dan menganalisanya agar dapat diimplikasikan pada pembelajaran Pendidikan Agama Islam. Hasil dari penelitian ini adalah bahwa potensi kecerdasan itu tidak tunggal tetapi majemuk (multi kecerdasan), meski semuanya bisa dikembalikan pada tiga jenis kecerdasan dasar IQ, EI dan SI. Dengan demikian keterkaitan multi kecerdasan dengan pengembangan pembelajaran terletak pada penolakan terhadap pembelajaran yang hanya mengembangkan aspek kognitif dengan mengabaikan aspek afektif dan psikomotorik. Hasil analisis juga menunjukkan beberapa implikasi pendekatan 
multi kecerdasan bagi 7 pembelajaran Pendidikan Agama Islam : Pertama, rumusan lebih mengarah pada mendorong peserta didik belajar optimal sehingga potensi (fitrah) dapat terahkan kepada kesempurnaan. Kedua, dengan mengetahui lebih dari satu kecerdasan memunculkan metode belajar yang kreatif, yaitu dengan menggunakan masing-masing kecerdasan sebagai strategi belajar. Ketiga, materi pelajaran harus berisi sekumpulan kemampuan yang berorientasi pada perilaku afektif dan psikomotorik dengan dukungan pengetahuan kognitif dalam rangka memperkuat keimanan dan ketakwaan kepada Allah SWT. Keempat, evaluasi berupa penilaian yang dapat menguji pemahaman mahasiswa tentang materi pelajaran secara lebih menyeluruh dan kontinyu.

Perbedaan dengan penelitian ini adalah bahwa penelitian ini meneliti 3 materi yaitu Konsentrasi IPA, Bahasa Indonesia dan Pendidikan Agama Islam, sedangkan penelitian di atas hanya memfokuskan pada satu materi yaitu Pendidikan Agama Islam. Selain itu, cakupan wilayah dan subyek kajian juga bukan pada pendidikan tinggi, melainkan pada sekolah menengah.

Dalam buku Gurunya manusia, dijelaskan panjang lebar mengenai bagaimana dan mengapa guru harus kreatif, buku tersebut banyak memberikan tips yang aplikatif dan bermanfaat bagi para guru. Tentu juga sangat bermanfaat bagi para calon guru Sekolah Dasar yaitu mahasiswa PGMI. Guru adalah sebuah profesi, profesionalitas guru sangat terkait dengan unsur manajemen kinerja guru, menurut Munif Chatib dalam bukunya tersebut jika kita mempunyai anggapan bahwa tidak ada peserta didik yang bodoh, maka kita juga harus percaya bahwa tidak ada guru yang tidak bisa mengajar. Masalah yang seringkali terjadi hanyalah pada kesulitan seorang pendidik untuk menuju tangga profesional.

Buku ini menjadi rujukan utama peneliti untuk terus melakukan riset pada kelas-kelas konsentrasi mahasiswa semester 7 prodi PGMI, dengan asumsi yang mengacu kepada pendapat Munif Chatib bahwa sesungguhnya pendekatan Multiple intelligences bisa diterapkan pada semua lini dan jenjang, yang membedakan ialah strategi pada setiap jenjangnya, prosedur aktivitas dan penilaiannya. ( Chatib, $2011:$ xvii) 
Buku kedua yaitu buku yang menjadi rujukan dari Munif Chatib, yakni Buku yang ditulis oleh Thomas Armstrong, The Best School, dalam buku ini Armstrong mengemukakan bahwa semua jenjang pendidikan mempunyai tujuan yang sama yaitu menjadi insan cendekia seutuhnya. Pendekatan multiple intelligences diterapkan pada jenjang manapun dan harus melihat pada perkembangan peserta didik, mulai dari tingkat prasekolah hingga masa remaja yang tujuan pendekatannya beralih fokus pada pembelajaran sosial, emosional dan metakognitif. (Armstrong, 2006 : 97)

\section{Landasan Teori}

Untuk memberikan gambaran teori yang digunakan dalam jurnal ini dan sebagai rujukan dalam penulisan selanjutnya, maka perlu dikembangkan teoriteori yang mendukung serta rujukan dalam pendidikan islam, antara lain Kullu mauluudin yuuladu 'alal fithrah. Setiap manusia dilahirkan dengan membawa potensi (fitrah) yang sama. Termasuk dalam hal ini adalah bahwa setiap manusia memiliki potensi (fitrah) kecerdasan yang sama. Kecerdasan tersebut memiliki banyak jenis. Akan tetapi, diantara berbagai kecerdasan yang dimiliki manusia akan menunjukkan derajat perkembangan yang berbeda. Potensi kecerdasan yang dimiliki oleh manusia akan berkembang sesuai dengan lingkungan dimana manusia tersebut berada. Oleh karena itu, kecerdasan tersebut akan memiliki pola perkembangan yang berbeda antar satu individu dengan individu lainnya.

\section{Pendekatan Multiple intelligences (Multiple intelligences Approach)}

Penemuan Gardner tentang intelegensi seseorang telah mengubah konsep kecerdasan, Menurut Gardner, kecerdasan seseorang diukur bukan dengan tes tertulis, tetapi bagaimana seseorang dapat memecahkan problem nyata dalam kehidupan. Intelegensi seseorang dapat dikembangkan melalui pendidikan dan jumlahnya banyak, hal ini berbeda dengan konsep lama yang menyatakan bahwa inteligensi seseorang tetap mulai sejak lahir sampai kelak dewasa, dan tidak dapat diubah secara signifikan. Bagi Gardner suatu kemampuan disebut inteligensi bila 
menunjukkan suatu kemahiran dan keterampilan seseorang untuk memecahkan masalah dan kesulitan yang ditemukan dalam hidupnya.

Menurut Gardner dalam diri manusia terdapat spektrum kecerdasan yang luas. Spektrum kecerdasan itu mencangkup tujuh jenis kecerdasan. Yaitu: (1) kecerdasan verbal, (2) kecerdasan visual, (3) kecerdasan logis-matematis, (4) kecerdasan musikal, (5) kecerdasan kinestetik, (6) kecerdasan intrapribadi (intrapersonal), (7) kecerdasan interpribadi (interpersonal), (8) kecerdasan naturalis, (9) kecerdasan eksistensial, dan (10) kecerdasan spiritual. (Gardner, 1993 : 97)

\section{Implementasi Multiple Intelligences dalam Kelas Tinggi}

Metode pembelajaran dengan pendekatan Multiple intelligences dalam pembelajaran dapat diimplementasikan dalam bentuk sebagai berikut: (Syurfah, 2007 : xixii)

1. Metode Mind mapping (peta pemikiran), Metode ini berfungsi untuk mengembangkan kecerdasan logis dan kecerdasan verbal.

2. Metode Brainstorming, Metode ini berfungsi untuk mengembangkan kecerdasan logis, keserdasan intrapersonal dan kecerdasan verbal.

3. Diskusi/ Sharing, Metode ini berfungsi untuk mengembangkan kecerdasan logis, interpersonal, dan kecerdasan verbal.

4. Tanya jawab, Metode ini berfungsi untuk mengembangkan kecerdasan logis, kinestetis, interpersonal dan kecerdasan verbal.

5. Metode presentasi, Metode ini berfungsi untuk mengembangkan kecerdasan logis, interpersonal, spasial dan kecerdasan verbal.

6. Tadabur alam, Metode ini berfungsi untuk mengembangkan kecerdasan logis kecerdasan naturalis dan kecerdasan verbal.

7. Metode Role play, Metode ini berfungsi untuk mengembangkan kecerdasan logis, kecerdasan kinestetik, kecerdasan spasial dan kecerdasan verbal.

8. Metode studi kasus, Metode ini berfungsi untuk mengembangkan, kecerdasan interpersonal, kecerdasan logis dan kecerdasan verbal. 
9. Metode cerita pengalaman, Metode ini berfungsi untuk mengembangkan kecerdasan kinestetik, kecerdasan intrapersonal, kecerdasan logis dan kecerdasan verbal.

10. Metode analisis film, Metode ini berfungsi untuk mengembangkan kecerdasan musikal, audio visual, logis dan kecerdasan verbal.

11. Metode analisis hikmah, Metode ini berfungsi untuk mengembangkan kecerdasan intrapersonal, logis dan kecerdasan verbal.

12. Metode interview, Metode ini dapat mengembangkan kecerdasan interpersonal, verbal, kinestetik dan logis.

13. Analisis instrumen, Metode ini dapat mengembangkan kecerdasan antara lain kecerdasan logis dan kenestetik.

14. Baca tartil, Metode ini berlatar belakang kecerdasan kinestetik dan verbal.

15. Field Trip (karya wisata), Metode ini dapat mengembangkan kecerdasan antara lain kecerdasan logis, verbal, naturalis, musical, interpersonal dan kenestetik.

16. Pengamatan, Metode ini dapat mengembangkan kecerdasan antara lain kecerdasan logis dan kenestetik.

17. Simulasi, Metode ini dapat mengembangkan kecerdasan antara lain kecerdasan logis, verbal, interpersonal dan kenestetik.

18. Perenungan, Metode ini dapat mengembangkan kecerdasan antara lain kecerdasan logis dan kenestetik.

19. Muhasabah, Metode ini dapat mengembangkan kecerdasan antara lain kecerdasan logis, kecerdasan intrapersonal dan kecerdasan spiritual.

\section{Koneksi Pendekatan Multiple Intelligences dengan peningkatan Life Skills}

Untuk menunjang keberhasilan pembelajaran, pada dasarnya adalah menentukan pendekatan pembelajaran yang sejalan dengan kurikulum tersebut. Membahas pendekatan pembelajaran, banyak sekali jenis pendekatan yang dapat diterapkan. Di antaranya pendekatan pembelajaran yang dikembangkan dari suatu teori yang dikenal dengan teori Multiple Intelligence. Teori tersebut digunakan sebagai pendekatan pembelajaran, karena di dalamnya membicarakan tentang keberagaman yang bertautan dengan kompetensi peserta didik. 
Pada dasarnya setiap kurikulum menitikberatkan pada pencapaian suatu kompetensi tertentu peserta didik. Pendekatan Multiple Intelligence pun memandang bahwa seseorang atau manusia memiliki beberapa potensi kecerdasan. Salah satu dari kecerdasan setiap peserta didik itulah yang harus dikembangkan, sehingga pada akhirnya menjadi suatu kompetensi yang sangat dominan penguasaanya.

Jika kita tautkan ketujuh kecerdasan yang dimiliki manusia dalam pembelajaran, maka dapat disimpulkan bahwa "Sebaiknya Multiple Intelligence (kecerdasan ganda) digunakan dan diterapkan sebagai pendekatan pelaksanaan kegiatan pembelajaran." Setiap manusia (peserta didik) tentu akan memiliki potensi yang sesuai dengan salah satu kecerdasan di atas. Dengan demikian, diharapkan salah satu potensi kompetensi dari peserta didik dapat muncul dan dapat dikembangkan.

Salah satu hal yang perlu diperhatikan dalam Multiple Intelligence adalah adanya tanggung jawab lembaga-lembaga pendidikan, dan kecerdikan seorang guru dalam memerhatikan bakat masing-masing peserta didik. Di dalam maupun di luar sekolah, setiap peserta didik harus berhasil menemukan paling tidak satu wilayah kemampuan yang sesuai dengan potensi kecerdasannya. Jika hal itu berhasil ditemukan dengan bimbingan pendidik, maka akan menimbulkan kegembiraan dalam proses pembelajaran, bahkan akan membangkitkan ketekunan dalam upaya-upaya penguasaan disiplin keilmuan tertentu, dan hal ini memiliki implikasi positif terhadap peningkatan kehidupannya atau yang biasa dikenal dengan istilah peningkatan life skills.

Kualitas sumber daya manusia Indonesia dewasa ini adalah cerminan dari sistem pendidikan yang saat ini berlaku. Kualitas sumber daya manusia adalah hasil dari penerapan sebuah sistem pendidikan. Bila banyak di antara kita tidak puas dengan sumber daya manusia Indonesia saat ini maka pada saat bersamaan secara tidak langsung kita sedang menggugat sistem pendidikan nasional karena kualitas sumber daya manusia kita belum bisa bersaing dengan negara-negara maju lainnya. Persoalan tersebut adalah pada pendidikan kita yang belum optimal 
dalam mengakomodir konsep kecerdasan majemuk (multiple Intelligence) dalam dua konteks: metode pembelajaran dan pendekatan kejiwaan peserta didik.

Dalam metode pembelajaran yang ada saat ini cenderung monoton dan membosankan. Hasilnya, anak didik sulit menerima atau memahami pembelajaran dari guru. Pendidik hanya mengetahui satu pola pembelajaran menerangkan kemudian latihan soal. Pola seperti ini sangat membosankan bagi anak-anak di usia sekolah dasar (SD dan SMP). Dengan pendekatan kecerdasan majemuk guru dituntut memahami keunggulan kecerdasan setiap anak. Teori kecerdasan majemuk ini menjelaskan bahwa setiap manusia memiliki kecerdasan yang berbeda. Dengan memahami kecerdasan manusia maka pendidikan bisa melakukan pendekatan pembelajaran sesuai dengan kecerdasan yang dimiliki pesera didik. Pendidik bisa mengemas metode pembelajaran sesuai dengan kecerdasan seorang anak. Bila pendekatan pembelajaran sesuai dengan kecerdasan anak maka peserta didik lebih tertarik mengikuti peroses pembelajaran. Dengan demikian materi pembelajaran akan lebih mudah ditangkap oleh peserta didik.

\section{Metodologi Penelitian}

Penelitian ini merupakan Penelitian R \& D (yang bersifat applied research) yaitu penelitian yang digunakan untuk mencari, mengembangkan dan menguji suatu produk atau temuan tertentu. (Subagyo, 1991 : 109) Jenis penelitiannya ialah penelitian Eksperimen dengan pendekatan campuran yaitu kualitatif dan kuantitatif, dimana penelitian ini memiliki karakteristik bahwa datanya dikondisikan dengan tidak mengubah dalam bentuk simbol ataupun bilangan karena lebih banyak wilayah kualitatif, sedangkan kuantitatifnya terkait dengan interpretasi data yang diperoleh dari tes dan angketnya. (Kountur, 2004 : 24) Dari segi perspektifnya juga penelitian kualitatif lebih menggunakan perspektif emic yang dalam pengumpulan datanya diungkapkan apa adanya, (Usman dkk, 1996 : 90) sehingga data yang diperoleh penulis diungkapkan sesuai dengan hasil yang diperoleh di lapangan tanpa ada interpretasi dalam bentuk bilangan. 


\section{Profil dan Pemilihan Lokasi Penelitian}

Pemilihan lokasi penelitian dilakukan di Institut Agama Islam Negeri Cirebon pada mahasiswa S1 PGMI dengan menggunakan purposive sampling. Adapun untuk subjek informannya ialah mahasiswa dengan mata kuliah konsentrasi Sains, Bahasa Indonesia dan konsentrasi PAI pada semester Tujuh di prodi PGMI, subjek ini diharapkan dapat memberikan informasi atau lebih ringkasnya ialah sumber data dalam penelitian adalah subjek dari mana data tersebut diperoleh, (Arikunto, 1998 : 102) menggunakan purposive sampling karena jumlah responden yang ditentukan memiliki tujuan untuk mewakili jumlah keseluruhan mahasiswa.

\section{Profil Responden Mahasiswa PGMI IAIN SNJ Cirebon}

Klasifikasi dibawah ini berdasarkan pada MIR (Multiple intelligences Research) dengan menggunakan teknik Interview, kuesioner, tes on line serta observasi. Beberapa peserta tersebut ialah :

1) M.Saifudin : Cenderung menyukai perdebatan dan kepiawaian dalam berbahasa. Sangat pandai dalam membuat apologi dan bernegosiasi. (kecerdasan Interpersonal)

2) Pirmansyah : Mencintai tumbuhan dan hewan, sangat menyukai aktifitas yang berkaitan dengan bercocok tanam. Seringkali menghasilkan produk yang terkait dengan agro. (kecerdasan Naturalis)

3) Henna N. Haena : sangat Rapi dan pandai membuat media pembelajaran yang interaktif, mampu menghasilkan karya seni dengan sangat detail dan selalu menghasilkan karya berupa media yang diselingi dengan musik, suara serta gambar (kecerdasan musikal \& intrapersonal)

4) Irna $D \quad$ : Ceria, suka bernyanyi di dalam kelas, pandai mengolah kata, dan sangat mudah bergaul (Kecerdasan bahasa \& Musikal)

5) PuputE : pendiam, lebih mudah dengan cara menyendiri, lihai dalam membuat kreasi ciptaan tangan, mencintai binatang (kecerdasan Naturalis) 
6) Rukoyah : Pendiam, pemikir ulung, penuh pertimbangan, kurang pandai bergaul namun pandai membuat tulisan yang indah dan sistematis (kecerdasan Intrapersonal)

7) Dianti O : Pendiam, menyukai musik korea, rajin menulis dalam diary (kecerdasan Intrapersonal \& Musikal)

8) Nina $\mathrm{M}$ : ceria, mudah bergaul, selalu bertanya, enerjik, menyukai belajar di luar ruangan (kecerdasan kinestetik)

Dari beberapa ilustrasi nama diatas, berdasarkan interview dan hasil tes kecerdasan diatas, menyimpulkan bahwa tidak selalu seseorang hanya cenderung pada 1 kecerdasan semata, akan tetapi beberapa kecerdasan mungkin saja bisa tereksplorasi dengan baik manakala sudah ditemukan. Dengan demikian setelah mengetahui jenis kecerdasan masing-masing langkah selanjutnya ialah mencari gaya belajar yang sesuai serta menyusun materi-materi yang mampu meningkatkan kecerdasannya, dan tidak membebani dengan materi yang tidak diminatinya.

\section{Teknik Pengumpulan Data}

Untuk memperoleh data dalam penelitian ini, penulis menggunakan beberapa metode dalam pengumpulan datanya, supaya memperoleh data yang benar-benar valid maka diperlukan berbagai metode bukan hanya satu saja, sebab masing-masing metode mempunyai kelebihan dan kelemahan sehingga satu sama lain saling melengkapi. Metode tersebut antara lain : tes, observasi, wawancara mendalam dan dokumentasi.

\section{Analisa Data}

Setelah data dapat dikumpulkan sesuai yang diharapkan dalam penelitian, maka langkah berikutnya adalah menganalisa dan memberikan interpretasi terhadap data. Dalam menganalisa data, penulis menggunakan metode analisa deskriptif, yaitu hanya semata-mata melukiskan keadaan obyek atau peristiwa tanpa suatu maksud untuk mengambil kesimpulan-kesimpulan yang berlaku umum. (Hadi, 1983 : 193) Metode analisa deskriptif inilah yang digunakan penulis dikarenakan metode ini sangat relevan, sebab kebanyakan data yang didapat dalam penelitian ini adalah bersifat kualitatif dan abstrak yaitu menyusun 
dengan cara mendeskripsikan, menafsirkan data dan menganalisa semua hal yang menjadi fokus dalam penelitian ini. (Muhadjir, 1998 : 30)

Data yang terkumpul dari berbagai sumber disajikan apa adanya kemudian dianalisis dengan menggunakan teknik interpretasi. Penyusunan teori dicapai dengan strategi induktif-empiris, yaitu berangkat dari rincian hal yang spesifik berdasarkan pengalaman nyata baik itu ucapan atau perilaku subjek penelitian maupun situasi lapangan yang ada untuk kemudian dirumuskan menjadi model ataupun konsep yang bersifat umum dengan tujuan untuk menemukan kategori, dimensi-dimensi dan hubungan antar hal yang penting. (Mulyana, 2004 : 156) Sebagai metode yang menggunakan analisa data non statistik, maka deskripsi data-datanya melalui bentuk kata-kata atau kalimat yang akan digunakan secara sistematis. Adapun langkah-langkah teknik analisis datanya sebagai berikut :

Reduksi data

Data yang diperoleh disusun secara sistematis kemudian dianalisis sejak dimulai penelitian. Data-data tersebut perlu direduksi, yaitu dengan memilih halhal pokok yang sesuai dengan tujuan penelitian. Data-data yang telah direduksi memberikan gambaran yang lebih tajam tentang hasil pengamatan dan akan lebih mempermudah penulis untuk menelusuri data tersebut berasal dari sumber mana, hal ini biasa dikenal juga dengan istilah koding data. (Moleong, 2002 : 288)

\section{Display data}

Display data dilakukan untuk menyajikan hasil data yang semakin banyak dan bertumpuk ke dalam bentuk matrik, bagan atau klasifikasi yang lebih tertata agar peneliti dapat menguasai data dan tidak terbenam dengan setumpuk data Pengambilan kesimpulan dan verifikasi

Pengambilan kesimpulan yang dilakukan pertama kali oleh peneliti mulamula kabur, tetapi lama-kelamaan kesimpulan tersebut akan semakin jelas karena data yang diperoleh semakin banyak dan mendukung. Verifikasi dapat dilakukan dengan singkat yaitu dengan cara mengumpulkan data baru. 


\section{Urgensi Pendekatan Pembelajaran berbasis Multiple Intelligences dikembangkan pada tingkat Perguruan Tinggi}

Perguruan tinggi adalah institusi formal tertinggi yang harus ditempuh oleh seseorang dalam bidang akademik, oleh karenanya materi-materi yang diberikan dalam perguruan tinggi semestinya mengarah kepada pembinaan kemandirian dan pendampingan kesiapan dalam bermasyarakat serta yang paling penting ialah perguruan tinggi merupakan salah satu wadah dalam meningkatkan life skill dari seseorang. Proses pembelajaran merupakan aktifitas yang sistemik yang terdiri atas banyak komponen. Masing-masing komponen pembelajaran tidak bersifat parsial (terpisah) atau berjalan sendiri-sendiri, tetapi harus berjalan teratur, saling bergantung, komplementer, dan berkesinambungan. Komponen tersebut antara lain bahan belajar, suasana belajar, media dan sumber belajar serta guru/dosen sebagai subjek pembelajaran.

Dosen mempunyai peranan penting dalam keberhasilan mahasiswa, sedangkan mahasiswa merupakan sasaran pendidikan yang sekaligus sebagai salah satu alat ukur dalam penentuan tingkat keberhasilan pada proses pembelajaran. Keberhasilan pembelajaran dalam arti tercapainya standar kompetensi, sangat bergantung kepada kemampuan dosen mengelola pembelajaran agar dapat menciptakan situasi yang memungkinkan mahasiswa belajar sehingga merupakan titik awal berhasilnya pembelajaran. Keberhasilan pembelajaran yang dituangkan dalam kurikulum perguruan tinggi tidak hanya semata pada ilmu dan ketrampilan yang dipilih oleh seorang mahasiswa namun juga didukung dengan pengembangan kepribadian, prilaku, berkehidupan bersama (Kepmendiknas No. 45/U/2002). Mahasiswa tidak hanya merupakan makhluk yang gemar belajar saja, ada begitu banyak tipe dan jenis mahasiswa di kampus. Tipe-tipe mahasiswa ini memiliki karakteristik yang berbeda pula. Karakteristik mahasiswa itu perlu diketahui agar kita mampu bersosialisasi dengan mereka mengenal watak dan karakter mereka. Masalah runtuhnya integritas akademik dan integritas moral di kalangan dunia pendidikan tinggi sejatinya adalah masalah yang paling mendasar bagi seluruh bangsa Indonesia. Karena, hampir semua 
pejabat tinggi negara, para wakil rakyat, para birokrat dan para teknokrat di negeri ini berasal dari lulusan perguruan tinggi.

Bertitik tolak dari pembahasan di atas, untuk memanifestasikan integritas akademik dan integritas moral bagi seluruh civitas akademika perguruan tinggi seharusnya seluruh civitas akademika perguruan tinggi memegang teguh asas-asas pendidikan tinggi. Banyak faktor yang menyebabkan kepribadian atau karakter mahasiswa memburuk. Hal ini dapat dilihat dari perilaku atau etika mahasiswa dalam belajar, mudah putus asa jika belum bisa, tidak jujur dalam belajar jika belum tahu untuk mengatakan saya belum tahu, kurang dapat menghargai pendapat teman, kurang demokratis, tidak disiplin dalam belajar, tidak mandiri dalam belajar, dan juga kurang kreatif. Pada pembelajaran biasanya mahasiswa yang kurang pandai dalam suatu materi, biasanya menunjukkan prilaku yang kontraproduktif dalam menyelesaikan soal. Misalnya, mereka membaca tetapi tidak memahami makna dari suatu pertanyaan, tidak mencerna informasi yang diperoleh, tidak yakin dengan cara yang digunakan untuk menyelesaikan soal, dan cepat menyerah ketika tidak tahu bagaimana menyelesaikan soal tersebut. Dari perilaku sehari-hari atau etika mahasiswa di kelas yang demikian yang mengakibatkan memburuknya karakter mahasiswa.

Berdasakan hasil pengamatan dan pengalaman di prodi PGMI selama ini, mahasiswa kurang terbuka apabila mengalami kesulitan dalam belajar baik kepada dosen, teman maupun orang lain terutama terhadap mahasiswa yang mempunyai kemampuan di bawah rata-rata. Mereka takut bertanya meskipun sudah dipancing dengan pertanyaan-pertanyaan yang merangsang daya fikir mereka. Mahasiswa cenderung malas belajar, cepat menyerah atau putus asa. Hal ini tampak dari kuis atau tugas yang diberikan dosen yang hasilnya tidak memuaskan bahkan kadang tidak dapat diselesaikan. Mahasiswa kurang aktif dalam kegiatan pembelajaran, mahasiswa tampak bingung, acuh tak acuh, bahkan ada sebagian mahasiswa yang sama sekali tidak memperhatikan penjelasan dari dosen atau teman, cepat putus asa pada saat dosen membimbing skripsi mahasiswa yang masih belum benar. Hal yang demikian menunjukkan lunturnya atau memburuknya karakter atau kepribadian mahasiswa. Memburuknya karakter tersebut implikasinya martabat 
bangsa Indonesia dinilai rendah oleh bangsa lain. Oleh karenanya peran institusi perguruan tinggi bisa merevitalisasi pendidikan dengan mengembangkan karakter mahasiswa melalui pembelajaran.

Dari uraian serta masalah yang terungkap jelas bahwa lunturnya karakter mahasiswa bukan hanya disebabkan faktor intern yaitu dari mahasiswa sebagi subjek dan objek pembelajaran, tetapi juga faktor ekstern yaitu dosen sebagai penyampai pelajaran. Oleh karena itu diperlukan usaha-usaha dan terobosan dosen untuk pengembangan nilai-nilai karakter mahasiswa dalam pembelajaran dengan penggunaan model ataupun pendekatan pembelajaran yang sesuai dengan tujuan mata kuliah, dan terutama yang mampu menyentuh hati mereka. Mendidik dengan hati dapat tercermin dari pendekatan multiple intelligences, hal ini dikarenakan proses pendekatannya yang mendasarkan pada potensi kecerdasan peserta didik. Mahasiswa lebih merasa dihargai dan tentu saja hal-hal yang terkait dengan minat masing-masing akan mampu lebih meningkatkan prestasi dan aktualisasi dirinya dan bahkan yang terpenting ialah motivasi belajar mahasiswa jauh lebih tinggi dibanding apabila mereka harus mempelajari materi-materi yang kurang diminati.

\section{Implementasi Pengembangan Pembelajaran Berbasis Multiple Intelligences Bagi Mahasiswa S1 PGMI IAIN SNJ Cirebon}

Dengan adanya implementasi multiple intelligences di lingkungan mahasiswa, maka ketertarikan sesorang terhadap suatu bidang dapat semakin terasah dan terekspos hingga kemudian akhirnya mereka dapat memahami dan menemukan potensi diri yang selama ini masih mereka cari. Usia remaja atau menginjak dewasa bagi beberapa mahasiswa merupakan fase yang pasti terjadi dan salah satu ciri dari fase ini ialah pencarian jati diri serta pencarian pengakuan akan eksistensinya. Bersinggungan dengan multiple intelligences bagi mahasiswa PGMI yang kami jadikan subyek penelitian membuat mereka menjadi lebih memahami arah hidup dan tujuannya, mereka juga mengenali potensi diri yang selama ini terpendam dan bahkan tidak jarang beberapa responden kami yang mengaku didalam salah satu interview riset bahwa masalah mereka bertahuntahun akhirnya terpecahkan dengan adanya talent mapping yang kami lakukan 
sebagai salah satu tehnik penggalian data kami. Dalam interaksi dan wawancara kami, Mahasiswa lebih terarah dalam hal gaya belajar, strategi belajar, dan bahkan pilihan pekerjaan yang nantinya akan mereka geluti. Dari hasil temuan ini 85\% responden sangat antusias dengan adanya implementasi multiple intelligences di perkuliahan, letak urgensinya ialah pada ketertarikan mereka terhadap penemuan gaya belajar yang cocok dan sesuai dengan kecerdasan masing-masing serta ketertarikan mereka terhadap pendalaman minat dan potensi diri masing-masing yang berimplikasi pada arah peningkatan life skill mahasiswa.

Dalam praktiknya, tidak semua materi pelajaran harus sekaligus memenuhi tuntutan mengembangkan semua jenis kecerdasan tersebut, tetapi bisa secara bertahap. Metode pembelajaran dengan prinsip kecerdasan mejemuk dalam materi perkuliahan dapat diimplementasikan dalam bentuk metode-metode pembelajaran yang bervariasi sesuai dengan kecerdasan yang dominan pada masing-masing mahasiswa. Menurut teori Multiple intelligences pemanfaatan kecerdasan yang tepat dalam proses pembelajaran akan sangat meningkatkan kekuatan belajar. Dengan kekuatan belajar tersebut maka hasil yang didapatkan akan lebih tampak. Dengan pembelajaran yang disesuaikan dengan kecerdasan yang dimiliki oleh mahasiswa maka mereka akan lebih termotivasi untuk belajar sehingga aktifitas belajar berjalan, peserta didik ikut terlibat aktif dalam proses di dalamnya dan hasil akhir yang diperoleh akan tercapai dengan adanya peningkatan, baik itu secara prestasi ataupun juga dalam life skillsnya.

Penerapkan pendekatan Multiple Intelligence dalam pembelajaran, harus memperhatikan beberapa langkah, meliputi:

1. Mengidentifikasi elemen-elemen Multiple Intelligence dalam program kurikuler dan ekstrakurikuler.

2. Meninjau kembali sistem teknologi dan program piranti lunak untuk melihat kecerdasan-kecerdasan apa yang terabaikan.

3. Para guru merenungkan kemampuan peserta didik, kemudian memutuskan untuk secara sukarela bekerjasama dengan rekan-rekan yang lain.

4. Proses pembelajaran dengan tanggung jawab tertentu, bisa dipilih sebagai metode pembelajaran. 
5. Diskusi dengan orang tua mahasiswa dan anggota masyarakat sehingga dapat membuka kesempatan-kesempatan magang bagi para mahasiswa.

Di samping langkah-langkah di atas, sebagai upaya untuk memadukan pendekatan Multiple Intelligence dalam pembelajaran, perlu juga memperhatikan hal-hal berikut:

1. Persepsi tentang mahasiswa harus diubah

Sebaiknya para pendidik memberikan perhatian kepada berbagai macam cara yang dilakukan mahasiswa untuk memecahkan masalah-masalah mereka dan mengaplikasikan apa yang telah mereka pelajari. Kita harus menerima bahwa peserta didik memiliki profil-profil kognitif dengan tingkat kemampuan yang berbeda. Pendidik harus menyediakan kesempatan-kesempatan belajar yang kaya, mempertajam kemampuan-kemampuan observasi mahasiswa, mengumpulkan informasi tentang bakat dan kegemaran mahasiswa, serta mempelajari kecerdasankecerdasan yang tidak biasa.

2. Pendidik membutuhkan dukungan dan waktu untuk memperluas daftar pengajaran

Jika proses pembelajaran ingin mencapai tujuan bahwa mahasiswa harus memiliki pengetahuan, nilai dan sikap, serta keterampilan yang seimbang, maka jam belajar yang selama ini hanya cukup untuk menguasai pengetahuan saja harus diubah dengan memperluas jam belajar. Hal ini perlu dilakukan untuk:

a. Memberi dukungan dan melakukan praktek.

b. Meminta pendidik tertentu yang memiliki kemampuan tinggi dalam sebuah kecerdasan untuk memberikan pelatihan.

c. Mengintegrasikan para spesialis yang memiliki keahlian dalam bidang tertentu.

d. Mengunjungi lokasi-lokasi lain sebagai bahan perbandingan proses pembelajaran.

3. Pendekatan Multiple Intelligence dan pembelajaran

Kurikulum pada dasarnya berfokus pada pengetahuan yang mendalam dan pengembangan kemampuan. Dalam hal ini, pembelajaran tidak harus menekankan pengajaran melalui kecerdasan, tetapi yang harus mendapat penekanan adalah 
bahwa pembelajaran itu untuk kecerdasan atau penguasaan kompetensi tertentu sesuai dengan minat dan bakat mahasiswa.

4. Diperlukan pendekatan baru terhadap proses penilaian

Ada beberapa hal yang perlu diperhatikan dalam aktivitas penilaian, yaitu:

a. Bagaimana menilai kecerdasan mahasiswa;

b. Bagaimana meningkatkan penilaian secara umum dalam hal kognitif, afektif, dan psikomotorik;

c. Bagaimana melibatkan mahasiswa dalam proses penilaian.

Adapun Langkah-langkah Implementasi model pembelajaran berbasis multiple intelligences bagi mahasiswa PGMI yang telah kami lakukan ialah :

a. Mengidentifikasi intelegensi mahasiswa.

Caranya dengan menggunakan tehnik talent mapping, yaitu sebelum memulai perkuliahan dosen memberikan tes atau angket kepada mahasiswa untuk menjajaki intelegensi mereka. Mahasiswa menjawab angket berdasar pada pengalaman pribadinya, hal ini dikarenakan angket atau tes berisi pertanyaan seputar aktifitas yang seringkali mereka lakukan. Referensi Isi angket yang peneliti gunakan merujuk kepada Tapping MI Thomas Armstrong dan Howard Gardner, selain itu peneliti juga menggunakan tes secara online dengan menggunakan web resmi Howard Gardner untuk memunculkan pilihan karir yang sesuai dengan kecerdasan masing-masing. Dengan demikian hasil angket dan tes bisa saling melengkapi dan bisa langsung dikoneksikan dengan karir yang akan dipilih. Setelah angket peneliti juga melakukan observasi, baik di kelas ataupun di luar kelas. Observasi di dalam kelas yaitu dengan mengamati apa yang dilakukan mahasiswa selama perkuliahan dan diluar kelas dilakukan dengan mengamati pergaulan mereka, baik di sela-sela waktu bahkan melalui media sosial yang biasa mereka akses. Dan tehnik talent mapping yang terakhir ialah interview mendalam, masing-masing mahasiswa diberikan sejumlah pertanyaan bebas yang nantinya mengerucut pada pilihan karir masing-masing dan bimbingan dalam peningkatan life skillnya. Berdasarkan beberapa tehnik penggalian data tersebut, peneliti menemukan data bahwa responden masih banyak yang belum terarah dan belum memahami kecerdasannya sendiri, sehingga hal tersebut berdampak pada ketidak 
jelasan pada gaya belajar dan pilihan karirnya. Setelah hal ini ditemukan peneliti berusaha mencari formula yang cocok antara gaya mengajar dosen dengan gaya belajar mahasiswa yang telah diketahui bidang kecerdasannya, dengan demikian diharapkan tujuan pembelajaran dapat tuntas, jelas dan mahasiswa lebih antusias untuk mengikuti perkuliahan sehingga perasaan bahagia yang mereka rasakan dapat melahirkan aktualisasi diri sesuai dengan harapan.

b. Menyusun prosedur aktifitas (SAP, dan kegiatan perkuliahan)

Prosedur aktifitas yang dimaksud ialah selama penyusunan SAP dan kegiatan perkuliahan, peneliti mengacu kepada strategi multiple intelligences, yaitu semua materi yang ada disampaikan dan pemberian tugas kepada mahasiswa berdasar pada kecerdasannya, semisal tema tentang "sayur organik", mahasiswa dengan kecerdasan naturalis tentu saja merasa pas dan cocok dengan tema tersebut. Mereka dengan kecerdasan ini langsung dapat menemukan ide untuk mengklasifikasikan tumbuhan yang menggunakan pupuk alami. Sehingga produk akhir bagi kecerdasan naturalis dengan tema sayur organik dapat dengan mudah dan jelas tergambar di benak mereka. Tentu saja hal ini berbeda dengan yang dialami oleh mahasiswa yang memiliki kecerdasan lainnya. Contohnya bagi mahasiswa dengan kecerdasan kinestetik, tentu tema ini tidak mudah, namun dengan bantuan adanya pemahaman bahwa antara gaya mengajar dosen dan gaya belajar mahasiswa harus sesuai dan cocok, maka peneliti menyarankan beberapa strategi kepada mahasiswa dengan kecerdasan kinestetik misalnya menanam sayur organik, dengan demikian mahasiswa kinestetik dapat lebih banyak bergerak dan produk akhirnya mereka mngetahui proses penanaman sayur organik dengan lebih baik. Hal diatas terkait dengan kegiatan perkuliahan mahasiswa, adapun yang terkait dengan SAP, dosen memberikan materi-materi dalam SAP kepada mahasiswa dengan meminta mereka untuk memilih sendiri tema-tema yang mereka sukai, dengan tujuan supaya mahasiswa melaksanakan kegiatan perkuliahan dan mengerjakan tugasnya dengan penuh antusias dan bahagia, tidak ada lagi unsur pemaksaan bahkan sejak dari awal perkuliahan. Strategi dan kegiatan perkuliahan yang mahasiswa lakukan kemudian dikonsultasikan dengan dosen, sehingga terjalin hubungan yang harmonis antara dosen dan mahasiswa 
serta dengan tujuan akhir yang hendak dicapai, tentu saja hal ini berdampak positif pada life skill mahasiswa dan positif terhadap gaya mengajar dosen.

c. Menyusun penilaian yang berbasis multiple intelligences

Dalam melakukan penilaian berbasis multiple intelligences dibutuhkan penilaian yang kompleks, baik dari tes, performance, produk, dan juga penilaian sikap. Dalam pelaksanaan penilaian, dosen memberikan tugas dan penilaian berdasar pada produk yang dikerjakan. Misalnya ketika terkait dengan mata kuliah Bahasa Indonesia tema "jenis sastra anak" maka produknya adalah "membuat puisi atau fabel tentang anak" bagi yang memiliki kecerdasan intrapersonal, namun bagi mahasiswa yang memiliki kecerdasan musikal, produknya ialah membuat sebuah lagu yang bertemakan tentang sastra anak. Dengan demikian kriteria yang dinilai sudah tepat mewakili masing-masing kecerdasan. Dan yang perlu dikaji ulang ialah penilaian yang terbuka dan adil.

d. Membimbing pemilihan karir yang berdampak secara ekonomis

Kesulitan memasuki dunia kerja seringkali menjadi permasalahan serius yang sering dihadapi oleh mahasiswa IAIN cirebon, khususnya mahasiswa PGMI, hal inilah yang kemudian memicu peneliti untuk membantu dan membimbing mahasiswa iain untuk lebih mampu dan lebih mapan untuk memasuki lingkungan masyarakat, tanpa harus berjubel-jubel mencari pekerjaaan. Tugas dosen berikutnya ialah bagaimana mereka menguasai bidang yang disukai dan dipilihnya, sehingga mereka bisa mandiri dan mapan. Pembelajaran berbasis multiple intelligences ini mampu mengarahkan mahasiswa untuk lebih jelas dan terarah dalam menemukan potensi dirinya dan tentu saja hal tersebut berdampak positif pada keberlanjutan karir masa depannya. Peneliti melakukan pendampingan dan pembimbingan kepada mahasiswa responden agar mereka mulai melahirkan produk-produk yang sesuai dengan bakat dan minatnya sebagai sarana aktualisasi diri yang juga memiliki nilai ekonomis. Misalnya beberapa mahasiswa mulai mengembangkan bisnis diawali dengan adanya materi rekayasa teknologi dalam bidang pangan "selai kulit pisang" adalah salah satu bentuk produk yang sudah mulai dijajakan dan yang sudah mulai dipasarkan pada khalayak ialah "abon lele". Melihat perkembangan mahasiswa mulai bersemangat 
untuk membangun kemandirian secara ekonomi setelah diberikan pembelajaran berbasis multiple intelligences ini, peneliti membutuhkan pengkajian lebih lanjut terkait dengan efektifitas dan produktifitas pembelajaran ini bagi dunia usaha.

\section{Implikasi Pembelajaran Berbasis Multiple Intelligences Terhadap Peningkatan Life Skills Mahasiswa S1 PGMI IAIN SNJ Cirebon}

Ada dua tahapan yang harus dilakukan agar mendapatkan hasil yang optimal, yaitu:

a) Memberdayakan semua jenis kecerdasan pada setiap materi

Secara empirik untuk menerapkan strategi pembelajaran MI dapat dimulai dengan melakukan reposisi pada kurikulum yang ada sekarang. Hal ini dilakukan dengan cara mengubah Tujuan Pembelajaran yang ada menjadi kompetensi yang diharapakan . Dengan demikian, setiap Tujuan atau pokok bahasan dituntut untuk memberdayakan semua atau sebagian besar jenis kecerdasan yang ada. Sebagai contoh mata kuliah bahasa yang dominan dengan kecerdasan linguistik, Kompetensinya berbunyi "mahasiswa dapat membacakan puisi dengan intonasi yang benar di depan kelas". Bila mereka melakukan semua itu dengan benar; maka kecerdasan yang terlibat akan meliputi: Kecerdasan Linguistik, MatematisLogis, Spasial Terbatas, dan Kinestetik-Jasmani saja. Akan tetapi bila Kompetensi diubah menjadi "mahasiswa dapat membacakan puisi dengan intonasi yang benar pada acara tertentu, atau di depan publik"; maka kecerdasan yang terlibat akan banyak lagi yaitu: Kecerdasan Linguistik, Matematis-Logis, Spasial Terbatas, Kinestetik-Jasmani, Interpersonal, Intrapersonal dan Naturalis. Dengan demikian kadar belajar yang diperoleh oleh mahasiswa akan jauh lebih tinggi dibandingkan apabila ia hanya membacakan puisi di depan kelas.

Pemikiran-pemikiran kreatif yang demikian inilah kemudian menunjukkan hasil belajar mahasiswa meningkat secara signifikan, dan berdasarkan observasi di lapangan menunjukkan adanya perubahan dalam sikap belajar mahasiswa. Mereka terlihat lebih aktif, percaya diri, dan kreatif dalam banyak hal.

b) Mengoptimalkan pencapaian materi tertentu berdasarkan kecerdasan yang menonjol pada masing-masing mahasiswa. 
Tahapan kedua ini ditempuh, ketika peneliti telah mengidentifikasi kecerdasan yang menonjol pada masing-masing mahasiswa. Sekali lagi, baik Gardner, maupun Amstrong, selalu mengingatkan bahwa ada satu atau lebih kecerdasan yang menonjol pada masing-masing individu (peserta didik). Bila kita menyadari hal ini, mengapa kita tidak mengoptimalkannya menjadi sesuatu yang bermakna bagi mereka. Atau menjadikannya sebagai jati dirinya, meskipun untuk bidang yang lainnya harus puas dengan standar minimal yang ditetapkan oleh lembaga.

Dalam penerapan tahap kedua ini strategi pembelajaran yang digunakan lebih bersifat personal atau individual. Mahasiswa yang memiliki kecerdasan Lingiustik misalnya, akan dioptimalkan pencapaian hasil belajarnya pada pendekatan Bahasa dan Sastra. Sedangkan mereka yang mempunyai kecerdasan Matematis-Logis misalnya, akan diarahkan pada pencapaian hasil belajar Matematikanya seoptimal mungkin melalui pemberian layanan individu dan akses ke berbagai kesempatan yang memungkinkan kecerdasan Matematikanya terus berkembang. Bagi mereka yang memiliki kecerdasan Spasial belajar dengan menggunakan media visual atau menggunakan peta konsep tentu sangat membantu mereka mencapai kesempurnaan belajarnya. Akan tetapi bagi mereka yang memiliki kecerdasan Kinestetik sangatlah tersiksa bila ia harus dipaksa duduk yang manis di dalam kelas. Mereka yang memiliki kecerdasan Kinestetik-Jasmani akan menghasilkan sesuatu secara optimal, bila mereka diizinkan belajar dengan cara melakukan gerakan-gerakan tertentu. Misalnya mengekspresikan suatu pesan dengan bahasa tubuhnya. Sedangkan belajar dengan alunan musik tentu sangat menyenangkan bagi mereka yang memiliki kecerdasan Musikal. Musik-musik klasik sangat dianjurkan sebagai pengiring bagi mereka memiliki kecerdasan Musikal ini. Dengan musik mereka akan menghasilkan sesuatu yang optimal dalam belajarnya. Lain pula halnya dengan mereka yang memiliki kecerdasan Interpersonal. Melakukan interaksi sosial adalah pilihan yang tepat bagi mereka yang memiliki kecerdasan Interpersonal ini. Sedangkan bagi mereka yang memiliki kecerdasan Intrapersonal tentulah sangat berterima kasih bila diizinkan belajar secara individual di tempat yang agak sepi, atau mengerjakan proyek individual. Untuk 
mahasiswa yang memiliki kecerdasan Naturalis akan efektif bila diarahkan pencapaian hasil belajar yang optimal untuk materi yang terkait dengan IPA. Belajar di luar kelas (outdoor) merupakan sesuatu yang menyenangkan bagi mereka yang memiliki kecerdasan Naturalis ini.

Paparan diatas merupakan hasil observasi dan interview kami selama proses riset ini berlangsung, dan kami dapati kenyataan bahwa mahasiswa jauh lebih antusias dalam mengikuti perkuliahan dan prestasi mereka ditunjukkan pada peningkatan life skillsnya yang cukup signifikan. Hal ini dikarenakan adanya perubahan pada gaya belajar dari yang bersifat konvensional beralih pada gaya belajar yang mengedepankan pada potensi kecerdasan mahasiswa, baik itu mahasiswa konsentrasi bahasa atau konsentrasi IPA dan bahkan konsentrasi PAI pada prodi PGMI.

Gaya belajar adalah cara yang konsisten yang dilakukan oleh seorang peserta didik dalam menangkap stimulus atau informasi, cara mengingat, berpikir dan memecahkan soal. Tidak semua individu mengikuti cara yang sama. Gaya belajar berkaitan erat dengan pribadi individu yang dipengaruhi oleh pendidikan dan riwayat perkembangannya. Gaya belajar adalah cara yang lebih disukai seseorang untuk memproses pengalaman atau informasi. Tipe-tipe gaya belajar yang dimiliki mahasiswa mempunyai pengaruh terhadap prestasi akademiknya termasuk di dalamnya kesesuaian gaya belajar dan ketidaksesuaian gaya belajar dengan kebutuhan dalam belajar. Langkah berikutnya setelah gaya belajar ditemukan adalah penerapan pembelajaran berbasis multiple intelligences agar life skills mahasiswa meningkat dengan signifikan.

Terdapat beberapa Implikasi pembelajaran berbasis multiple intelligences terhadap peningkatan life skill, yaitu kecakapan yang diperlukan untuk hidup dalam kehidupan dan penghidupan seseorang, antara lain :

a. Keberanian dan kemauan menghadapi masalah kehidupan secara wajar,

b. Secara kreatif menemukan solusi mengatasi masalah, dan

c. Kecakapan memecahkan masalah kehidupan, mencari dan menciptakan pekerjaan. 
Indikator-indikator yang terkandung dalam life skills tersebut secara konseptual dikelompokkan : (1) Kecakapan mengenal diri (self awarness) atau sering juga disebut kemampuan personal (personal skills), (2) Kecakapan berfikir rasional (thinking skills) atau kecakapan akademik (akademik skills), (3) Kecakapan sosial (social skills), (4) Kecakapan vokasional (vocational skills) sering juga disebut dengan keterampilan kejuruan artinya keterampilan yang dikaitkan dengan bidang pekerjaan tertentu dan bersifat spesifik (spesifik skills) atau keterampilan teknis (technical skills).

Telah terjadi pergeseran nilai hidup dari sebagian mahasiswa dari menuntut ilmu dan berkarya ke menikmati hidup dan menikmati karya. Dengan kata lain kurangnya internalisasi Tri Dharma Perguruan Tinggi di kalangan mahasiswa. Imbasnya, mahasiswa lebih suka berdemo menuntut pemerintah membatalkan kebijakan yang dianggap merugikan masyarakat daripada berkarya untuk mengatasi tantangan yang dapat berguna bagi rakyat. Seharusnya mahasiswa yang kreatif dan bermoral tinggi memiliki kepekaan yang lebih berupa tindakan nyata dan langsung sebagai bentuk pengabdian kepada masyarakat. Dunia pendidikan adalah tempat dimana mahasiswa berkecimpung. Hakikat pendidikan adalah membentuk manusia seutuhnya. Seutuhnya berarti tidak berperilaku seperti binatang, dengan kata lain berperilaku sesuai akal pikiran dan hati nurani. Berperilaku sesuai dengan akal, pikiran dan hati nurani berarti berdasarkan nilai-nilai moral. Diperlukan pendidikan yang secara khusus merujuk pada soft skill mahasiswa sebagai dasar berperilaku akademis, yakni antara lain tercermin dari pendidikan berbasis multiple intelligences yang secara praktis mampu meningkatkan kecakapan hidup seseorang dan tentunya juga bermanfaat bagi lingkungannya.

Dengan bekal kecakapan hidup yang baik, diharapkan para lulusan perguruan tinggi akan mampu memecahkan problema kehidupan yang dihadapi, termasuk mencari atau menciptakan lapangan pekerjaan bagi mereka yang tidak melanjutkan pendidikannya. Berdasar pada indikator life skills tersebut, jelas terlihat bahwa pembelajaran berbasis multiple intelligences mampu 
mengakomodir semua kecakapan yang diinginkan, hal ini dibuktikan dengan banyaknya kelebihan dan manfaat yang didapat dengan menggunakan pendekatan ini daripada madharatnya, salah satu kelebihannya dan yang sering terlupakan menurut peneliti ialah "mendidik dengan hati"

\section{Simpulan}

Urgensi model pembelajaran berbasis multiple intelligences dikembangkan pada tingkat Perguruan Tinggi berdasakan hasil pengamatan dan pengalaman di prodi PGMI selama ini, mahasiswa kurang terbuka apabila mengalami kesulitan dalam belajar baik kepada dosen, teman maupun orang lain terutama terhadap mahasiswa yang mempunyai kemampuan di bawah rata-rata. Mahasiswa kurang aktif dalam kegiatan pembelajaran, mahasiswa tampak bingung, acuh tak acuh, bahkan ada sebagian mahasiswa yang sama sekali tidak memperhatikan penjelasan dari dosen atau teman, cepat putus asa pada saat dosen membimbing skripsi mahasiswa yang masih belum benar. Hal yang demikian menunjukkan lunturnya atau memburuknya karakter atau kepribadian mahasiswa. Memburuknya karakter tersebut implikasinya martabat bangsa Indonesia dinilai rendah oleh bangsa lain. Oleh karenanya peran institusi perguruan tinggi bisa merevitalisasi pendidikan dengan mengembangkan karakter mahasiswa melalui pembelajaran. Dari uraian serta masalah yang terungkap jelas bahwa lunturnya karakter mahasiswa bukan hanya disebabkan faktor intern yaitu dari mahasiswa sebagi subjek dan objek pembelajaran, tetapi juga faktor ekstern yaitu dosen sebagai penyampai pelajaran. Oleh karena itu diperlukan usaha-usaha dan terobosan dosen untuk pengembangan nilai-nilai karakter mahasiswa dalam pembelajaran dengan penggunaan model ataupun pendekatan pembelajaran yang sesuai dengan tujuan mata kuliah, dan terutama yang mampu menyentuh hati mereka.

Implementasi Pengembangan pembelajaran berbasis multiple intelligences bagi mahasiswa S1 PGMI IAIN SNJ Cirebon membuat ketertarikan sesorang terhadap suatu bidang dapat semakin terasah dan terekspos hingga akhirnya mereka dapat memahami dan menemukan potensi diri yang selama ini masih 
mereka cari. Dalam interaksi dan wawancara kami, Mahasiswa lebih terarah dalam hal gaya belajar, strategi belajar, dan bahkan pilihan pekerjaan yang nantinya akan mereka geluti. Dari hasil temuan ini $85 \%$ responden sangat antusias dengan adanya implementasi multiple intelligences di perkuliahan. letak urgensinya ialah pada ketertarikan mereka terhadap penemuan gaya belajar yang cocok dan sesuai dengan kecerdasan masing-masing serta ketertarikan mereka terhadap pendalaman minat dan potensi diri masing-masing yang berimplikasi pada arah peningkatan life skill mahasiswa.

Implikasi pembelajaran berbasis multiple intelligences terhadap peningkatan life skill bagi mahasiswa S1 PGMI IAIN SNJ Cirebon antara lain terdapat beberapa Implikasi pembelajaran berbasis multiple intelligences terhadap peningkatan life skill, yaitu kecakapan yang diperlukan untuk hidup dalam kehidupan dan penghidupan seseorang, antara lain:

a. Keberanian dan kemauan menghadapi masalah kehidupan secara wajar,

b. Secara kreatif menemukan solusi mengatasi masalah, dan

c. Kecakapan memecahkan masalah kehidupan, mencari dan menciptakan pekerjaan.

\section{Daftar Pustaka}

Adi W. Gunawan. Genius Learning Strategy. Jakarta: Gramedia Pustaka Utama. 2006.

Ariany Syurfah, Multiple intelligences For Islamic Teaching. Bandung: Syamil., 2007.

Budiningsih, C. Asri. Belajar dan Pembelajaran. Jakarta: Penerbit Rineka Cipta. 2005.

Deddy Mulyana, Metodologi Penelitian Kualitatif, Bandung : Rosda Karya, 2004.

Dryden, Gordon \& Jeannete Vos. Revolusi Cara Belajar. Bandung: Kaifa. 2002.

Hamzah B. Uno, Mengelola Kecerdasan dalam Pembelajaran, Jakarta : Bumi Aksara, 2009. 
Howard Gardner, Multiple intelligences, Alih Bahasa Drs. Alexander Sindoro, Interaksara, 2003.

Husaini Usman \& Purnomo Setiady, Metodologi Penelitian Sosial, Jakarta : Bumi Aksara, 1996.

Ign. Gatut Saksono, Pendidikan Yang Memerdekakan Siswa, Yogyakarta : Yabinkas, 2008.

Irmayanti, dkk. La Tahzan for Teachers. Jakarta: Lingkar Pena Kreativa, 2010.

Julia Jasmine, Panduan Praktis Mengajar Berbasis Multiple intelligences, Nuansa, Bandung: 2007.

Lexy J. Moleong, Metodologi Penelitian Kualitatif, Bandung : Rosda Karya, 2002.

Muhammad Idrus, OrientasiAlternatif bagi Pendidikan Nasional, Jurnal Studi Islam Mukaddimah No. 9 Th. VI 2000, UIN Sunan Kalijaga: Yogyakarta: 2000 .

Munif Chatib, Sekolahnya Manusia; Sekolah Berbasis Multiple intelligences di Indonesia, Bandung : Mizan, 2009.

-----------, Gurunya Manusia;Menjadi Guru yang dirindukan Siswa, Bandung : Mizan, 2011.

Noeng Muhadjir, Metode Penelitian Kualitatif, Yogyakarta : Rake Sarasin, 1998.

P. Joko Subagyo, Metodologi Penelitian dan Praktek, Jakarta : Rineka Cipta, 1991.

Robiah al-Adawiyah, dkk. Agar Ngampus Tak Sekedar Status. Solo: Indiva Media Kreasi, 2008.

Ronny Kountur, Metode Penelitian untuk Penulisan Skripsi dan Tesis, Jakarta : PPM, 2004.

Subandijah, Pengembangan dan Inovasi Kurikulum, Grafika Persada, Jakarta: 1996.

Sugiyono, Metode Penelitian Pendidikan; Pendekatan Kuantitatif, Kualitatif dan $R \& D$, Bandung : Alfabeta, 2008.

Suharsimi Arikunto, Metodologi Penelitian Suatu Pendekatan Praktek, Jakarta : Rineka Cipta, 1998. 
Sutrisno Hadi, Metodologi Research II, Yogyakarta : Badan Penerbit Fakultas Psikologi UGM, 1983.

Thomas Armstrong, Setiap Anak Cerdas, Jakarta: Gramedia, 2002.

-----------, Multiple intelligences in The classroom, USA : ASCD, 2000.

---------, The Best School, USA : ASCD, 2006.

Thomas R. Hoerr, Buku Kerja Multiple intelligences, Kaifa, Bandung: 2007.

Tony Buzan, Use Both Side of Your Brain. Surabaya: IKON. 2004. 